\author{
Miroslav SOMR, HELENA PAVLiČÍKOVÁ \\ University of South Bohemia \\ České Budějovice
}

\title{
COMENIUS' ETHICAL VISIONS OF THE IMPROVEMENT OF HUMAN THINGS
}

\begin{abstract}
Somr Miroslav, Pavličíková Helena, Comenius' Ethical Visions of the Improvement of Human Things [Wizje etyczne Comeniusa o doskonaleniu człowieczeństwa]. Studia Edukacyjne nr 35, 2015, Poznań 2015, pp. 395-404. Adam Mickiewicz University Press. ISBN 978-83-232-2904-9. ISSN 12336688. DOI: $10.14746 /$ se.2015.35.21
\end{abstract}

The paradox about the Reformation is that, rather than consolidating European Christendom, it contributed to deepening the rifts between Catholics and Protestants as well as Lutherans and Calvinists, bringing about religious and civil strife. Comenius got involved in the antagonistic circumstances through his political philosophy, aspiring to weeding out the causes of hatred and mutual disagreement. This abiding endeavour of his achieved prominence in Panorthosia (Universal Improvement), which renders his best vision of permanent reconciliation resting upon educational, religious and civil reforms. Comenius' ethical pursuit of improving human matters is rooted in his philosophical thought regarding man as an individual whose purpose in this world is to be humane: wise, moral and pious.

Key words: Protestantism, stoicism, chiliasm, pansophia, pampaedia, political philosophy, political conservatism, Eruditio, Religio, Politica, Panorthosia

\section{Introduction}

Born early in the epoch whose close we are approaching, John Amos Comenius equally witnessed the advancement and crisis of modern science, utopian plans for a just social arrangement, and the horrors of wars and revolutions. His was the time when people carried out their worthy endeavours to dominate Nature, which, being gradually threatened, made it obvious that the would-be masters' civilisation itself was in danger since Nature 
turned its back on them ${ }^{1}$. Throughout Comenius' lifetime (1592-1670) the foundations of modern European society were instituted in economic, cultural, political, ideological and religious clashes, from philosophical and scientifical contradictions, and amid ethical and social controversies. The 16th century saw the rise of reformation attempts at rectifying the power abuses concomitant with the medieval hegemony of Catholic Church.

The original intention of the Reformation, however, as the case may be in such stages of human development, failed to achieve its goal - instead of bringing European Christianity to unifying ideological reconciliation within an integrated creedal community, it incited deep hatred and bitter controversy. Moreover, it brought about dissidence within the emergent Reformation movement, factually, fierce polemics and quarrels among Protestants. As a result, the Protestant struggle against the power of dogmatic stereotypes in Europe ended in a new dilemma and intolerance, which led to an unsparing confrontation of two resentful groupings - Luterans and Calvinists. Their respective leaders - Martin Luther (1483-1546) in Germany and Jean Calvin (1509-1564) in France - thus initiated contention, a time of religious and civil antagonisms to dethrone conciliation and faith as mainstays in the European area.

Another influence were the Netherlands' revolt against Spain and the English civil war, which in the late 16th century and in the mid-17th century, respectively, opened up new horizons for social and civil activities, enabling the advancement of science and technology - literally, an inflow of 'the light of spirit' to illuminate the world's stage. At the same time, the two events identified the point of discord, i.e. the contradiction between science and belief demonstrating that their disagreement was not a merely external effect but the essence of all 'that is going on' here.

Such was the prevailing climate at the birth of John Amos Comenius, a man whose credo was promoting harmony and integration along with moral consciousness and human understanding. Nevertheless, his vision was predetermined by Hapsburg expansion, which in a symbiotic relationship with the Catholic counter-Reformation molded the fabric of feudal autocracy.

In Comeniology, the image of labyrinth as an epitome of contradictions and conflicts is traditionally connected with the historical reality of the 17th century. Sometimes it is identified with the upheavals following the 1620 defeat of the estates by Hapsburgs, at other times it is removed back to the Czech insurrection of 1618-16202.

${ }^{1}$ J. Pešková, Aktuální aspekty filosofické argumentace v Komenského „Konzultaci“, Filosofický časopis, 1992, 40, 1, p. 5.

2 J. Pánek, Politické labyrinty Jana Amose Komenského, Filosofický časopis, 1992, 40, 1, p. 82. 
The concurrent dramatic conflicts and fights, however, provided more than background to human stories: casting the full strength of their antagonisms right on the lives of people, they were bound with every fleeting moment of their inner life, giving an enduring picture of impermanent life on the stage of the world.

The fact remains that the inner conflicts helped radicalise religious movements which shifted the gist of the conflict from religious to secular issues, from religious dogma to the enlightened ideal of science and learning, while major social rifts were partly concealed by the new belief in their 'saving' mission?

\section{Belief and love}

Comenius entered this world espoused by the most precious and genuine assets - that is to say, the unwavering belief imposed on him by the Moravian Church (Unitas Fratrum) and an unremitting idea that one's purpose in life is based on effort, endeavour, wisdom, morality and piety. Love, belief and hope, which marked Comenius' early thinking, obviously became his ideal of humaneness, the ethical value of events, and, in his mind, the very outset of the individual's positive attitude to life. Comenius attempted to set up an ideal world which we approach through our actions, creating a basis for our intuition. In the span of his life, the ideal of humanity evolved toward greater prudence and specificity, becoming more liberal, more visionary and more philosophically predictive. It effectively interconnected the rich diversity of Nature, ethics and politics, the centre of which was inhabited by wise, moral and pious man. In this respect his was a Socratic move towards the philosophy of man, namely, a vision of world improvement to support the change of the existent to the future picture, to the light of the world. An important aspect of these efforts appeared to be their mutual interrelation within a consistent, organic system prioritising the activity of man. The fundamental image and content of Comenius' philosophy was an action, whatever activity.

From the very beginning, Comenius' philosophising can be referred to as efforts, rather than opinions or problems. Thus efforts develop from their aims, which, early on, are intended for his nation, then they gradually achieve goals common to all mankind, proceeding from individual target areas to grouping or merging in a high-

${ }^{3}$ M. Somr, Muže naděje a touhy, posel budoucnosti, České Budějovice 1999, p. 63. 
minded synthesis of all efforts. In the first period, efforts can be characterised as omniscient, all-enlightening, all-formative ${ }^{4}$.

Early intellectual stimuli to Comenius' ideas can be traced to his studies at the Herborn Academy and the University of Heidelberg (1611-1614) 5 .

The idea of creating an optimum picture of the world was borrowed by Comenius from Heinrich Alsted (1588-1638), who promoted arranging all knowledge according to an ideal model harmonising secular erudition with the biblical revelation. It may have been already where the twenty-year-old scholar began to conceive the essentials of his thought - consisting not in a detached analysis but in systemisation of the picture of events with respect to methaphysical prospects ${ }^{6}$.

Among other university tutors who had their share in the formation of Comenius' political and philosophical conceptions, three names are certainly worth mentioning: Johann Fischer-Piscator (1546-1625) with his theory of dynamic harmony; Johann Althusius (1563-1638) and his ideas of subsidiarity and consocialism; and David Paré (1548-1622), a supporter of ecumenical settlement of conflicts within Evangelical churches ${ }^{7}$. Far from exhaustive, our list could hardly be complete without the names of thinkers whose influence on Comenius has already been thoroughly examined, let us single out but a few: Galileo Galilei (1564-1642); Francis Bacon (1561-1626); René Descartes (1596-1650); Thomas Hobbes (1588-1679); and others.

One of Comenius' earlier tracts on moral and social issues of his time was published under the title of 'Listové do nebe' [Letters to Heaven] in Olomouc in 1619. The author tackled in it a crucial philosophical and theological question: how can God, who is kind and righteous, tolerate oppression and injustice?

Its literary style is very attractive, using a dialogue in the form of letters exchanged between the poor, the rich and Christ. Comenius sympathises with the poor, yet his solution is conciliatory, a compromise appeal for tolerance, patience and compassion ${ }^{8}$.

Comenius did not specify here the main causes of differences between the rich and the poor worlds, nor did he imply criticism. Notwithstanding

4 J. Popelová, Filozofia Jana Amosa Komenského, Bratislava 1985, p. 13.

5 J. Červenka, Problematika Komenského metafyziky, Studia Comeniana et historica, 1973, 6, p. 25.

6 J. Pánek, Politické labyrinty Jana Amose Komenského, Filosofický časopis, 1992, 40, 1, p. 87.

7 Comenius. Erkennen - Glauben - Handeln. Internationales Comenius-Colloquium Herborn 1984, Sankt Augustin 1985.

8 J. Kumpera, Jan Amos Komenský, Ostrava 1992. 
he addressed the contemporary social problems and his appeal to the rich for amendement, the overall message inclines toward the tradition of mutual tolerance typical of the Unitas Fratrum.

Comenius was convinced that injustice follows from a multitude of human sins. According to Comenius, no-one but Jesus Christ can distinguish between good and evil in the earthly contention. Anyway, his text reveals strong moral and social feeling of the author who identifies himself with the poor, with the humility and lowliness they show when addressing God, because there is no man to whom they could deliver their lamentations. Standing alone before Christ, they suffer the feeling of loneliness which shows their mental anguish and human helplessness. Comenius' solution, however, does not point to conflict, to the contradiction between revolt and one's own resistance. The rich remain their brethren and the plea of the poor is sent even to their world. Comenius was deeply convinced of the value of faith and so he emphasised that Jesus could not remain indifferent to the appeal of the poor, since their complaint was actually an impassioned prayer towards him. Human pain and despair were transferred from the existing world to the divine world.

The ethical dimension of the issues which arised from social arrangement Comenius found in the divine justice. Meekness before the Creator was objectified in daily frugality and scarcity, which were the path to man's happiness. Therefore one could not choose the way of rebellion, for even wealth and social inequality were rightful in the parity of all people before God. There Comenius went beyond the level of mere contemplation: his social conscience and moral conviction led him to those who were destitute in this world. It is only proper to remark that an indisputable influence on Comenius' thought was Seneca as one of the leading representatives of stoicism.

For all that, Comenius could not adopt his way of thinking as the solution inferred one's own destruction. Comenius' diversion from the antinomy of life was, by contrast, counterbalanced by his belief in human activity for the benefit of one's own and of the others' as well. His obligingness was determined by man's origin, regarding man as God's creature, Comenius was an adversary of violence, controversy, rancour, malice and hate. All grievances and complaints end in accepting a compromise appeal for tolerance, patience and mercy. Impelling the rich to improvement was rejected because they saw the causes of poverty mainly in the lack of application and diligence among the poor. Eventually, the moral appeal ended in admitting what it was - an appeal for reconciliation. Hence summing up Comenius' thought in the early 17th century through the titles of two of his more recent tracts may read: the Light from Darkness ends in the Light in Darkness. 


\section{In the world's labyrinths}

The mystical and chiliastic atmosphere of the discordant 17th century was reflected in Comenius' collections of prophecies, 'Lux e tenebris' [A Light Shining from the Darkness] (1665) and 'Lux in tenebris' [A Light Shining in the Darkness] (1657). The condition of helplessness and wise stoical resignation was instrumental in defending the existing social situation through a moralising tract, or a poignant dialogue. The Czech philosopher Jiřina Popelová demonstrates that

open apologetics defends a particular situation or a particular class position by lauding its advantages. Indirect apologetics does not disguise contradictions and weaknesses, instead it lessens the blame for it by interpreting it as a natural attribute of human existence and life as such?.

Consequently, whatever war against it is not only vain but, on the whole, futile and the implicit pessimism philosophically substantiates the absurdity of any political action. Though greatly pessimistic, these ideas were of cardinal moral importance which helped him overcome the grievous tone, bringing solace to himself and his peers as well. Rather than call to arms, these reflections were intended as a plea for tolerance of the inescapable lot. A herald of human reconciliation, Comenius was a staunch advocate of the idea that the days of ordeal must be endured until the last. It will be followed by a breakthrough -a return to the realm of good - and all who will have gone through this suffering will reach ultimate redemption.

At heart, Comenius' ethical tone was too humane to be real in a secular world. Comenius came to a conclusion which was in full conformity with his faith and fatefulness deeming human destitution natural and leaving the solution in the hands of God. He held for true that all the poverty in the world, this grand stage of our destinies, was man's lot and the response was in the hands of Christ as the only judge of all people, alive and dead. That is why Comenius' appeal, ushering in humble belief in magnanimity and righteousness of every individual according to their deeds, was addressed to him. To Comenius, faith represented love - not only love of God but love of man. Love as man's esteem for man, quite in the spirit of the Commandment saying - you shall love thy neighbour as you love yourself. This plea concerned everyone and was expressed on behalf of everyone.

Comenius' work 'Listové do nebe' was rather a plea (not an accusation) on behalf of those who were the children of the Creator. This world's expectations should be sat-

${ }^{9}$ J. Popelová, Filozofia Jana Amosa Komenského, p. 34-35. 
isfied through the patience of the poor and through the charity ot rich. Was it a world of waiting? No. It was a world of reconciliation, big hope and expectation, which charged even the life of Comenius. Christ would come soon. This is where lay the strength of his belief in the justice of the last judgement, for which all of us should be prepared ${ }^{10}$.

\section{The improvement of the world and man}

In the time following the Czech national catastrophe after the battle of White Mountain (1620), Comenius' thought, despite bringing consolation, surrendered to futility. Scarcely withdrawing, he set on the road to comprehensive inquiry into the world's historical development. In the dialogical tract 'Truchlivy' [The Mournful] (Vol.1 completed in 1623, the others followed in 1624, 1650 and 1660) Comenius pushed the historical aspect to the utmost limit, referring to real human affliction liable to bring man to the edge of the 'precipice', i.e. loss of faith in God. Man's ordeal became so inhuman that it suppressed the power of faith, because such intensive evil, according to Comenius, could not be the work of God. Man's humiliation was highly immoral and the world's penury inhuman. This was what made Comenius take up a defensive position, but

this struggle cannot be won by faith. It is too weak to outwit the arguments of reason and to escape the torment of heart. Now it is time to evoke the very vision of Jesus Christ; thus salvation is not sought in theology but in mysticism ${ }^{11}$.

Comenius' loss of religious conviction led him to thoughtful doubts - namely, how could God leave his faithful followers at the mercy of their enemy? The reason for 'Truchlivy' being often deemed the most philosophical of his works may be grounded in the fact that the author raised therein poignant questions arising from the outburst of despair. In John Amos Comenius, the strife between belief and reason was connected with the disaster of his nation, with the country he had had to leave ${ }^{12}$.

In 1632-1633 Comenius completed 'Renuntiatio mundi', in which he pondered on the condition of the world and where his rebellion against the world assumed a more distinct shape conveying deliberate malice and condemning the world of violence and suffering. He voiced trenchant criticism of wile and falsehood, of unrestrained greed, of wickedness, hate and envy, ignorance of God, of hypocricy and vanity, and disobedience of God's

${ }_{10}$ M. Somr, Muže naděje a touhy, posel budoucnosti, České Budějovice 1999, p. 42.

${ }^{11}$ J. Popelová, Filozofia Jana Amosa Komenského, p. 41.

12 Ibidem, p. 40. 
Commandments. The world is described as an enormous Babylon, which blends everything and which everybody must leave to achieve salvation. Comenius himself overcame this tormenting crisis and entered the path of hope, since his faith and expectations were more powerful than his personal and national harrowing devastation.

In the mid-17th century Comenius experienced intellectual regeneration linked with the efforts to formulate his vision and to improve the world and man. In this regard, mention must be made of his masterly treatise 'De rerum humanarum emendatione consultatio catholica', the most comprehensive and daring synthesis a Czech thinker ever ventured to complete. Comenius managed to interweave his whole-hearted love of freedom with education and learning, showing the interconnection of political philosophy and the philosophy of education and morals. His achievement was a genuinely new and original system interlinked through the reforms in one trinitarian volume: Eruditio-Religio-Politica. As a political philosopher, Comenius proved to be aware of the necessity not only to explain the current situation, but also do one's best to improve it.

Admittedly, tackling power clashes and religious strife was a 'mammoth' task, especially when faith had deviated from its original purpose i.e. not to divide people but reconcile and unite them on the road to human perfection and personal responsibility. For Comenius, the greatest evil was war, which he deemed bestial, not only condemning it but, later on, utterly rejecting it, refusing to equate it with fight for freedom or in the name of 'just peace'.

It was in 'De rerum humanarum emendatione consultatio catholica' that the outline of path to improvement and elimination of hate was substantiated in the form of peace project included in the sixth chapter, entitled 'Panorthosia'. Dispensing with the visionary and comforter's view of the world, it brings an integrated and elaborate plan to deal with the issues, because human mind naturally longs for freedom. Good and justice, hope and desire for peace are ethical values promoted in the European plan as follows: unity in common interests, freedom in different subjects, and love in all.

It is absolutely necessary for mankind to aspire to restoring freedom of thought, freedom of belief' and citizen's freedom. For freedom, I maintain, is the most precious human asset, created along with man, and inalienable" 13 .

'Panorthosia' became a coherent project of all-mankind peaceful arrangement of essential spheres of life. This project was grounded in the idea

${ }^{13}$ J. Popelová, Filozofia Jana Amosa Komenského, p. 41. 
of improving public education, religion and government. 'Panorthosia' introduced universal improvement of all, in all, and for all purposes. Comenius conceived a project of all-mankind improvement aimed at suppressing evil and discovering the true light of wisdom, and at overcoming contradictions. Apart from the religious sphere, the improvement should affect civic and philosophical scopes. Conformably, it was incorporated into the area of societal improvement, with special emphasis on the social sphere.

The all-improvement, let alone conciliation on the road to advancement, was to be achieved by implementing cultivated philosophy and politics. By following Hussite teaching embracing the idea of world improvement, Comenius also consummated the vision of the Moravian Church.

Commenius is a true heir of the dream of an equitable arrangement of relations between nations and within nations...Comenius conceives the path to truth not as commitment to fighting each other but to supporting each other. The quest for truth must be a common pursuit, joint endeavour to seek and find it. On that account he chooses the form of counselling (consultatio) ${ }^{14}$.

Comenius may have called for summoning strength, for involvement, all the same he accentuated the ability to reason and explain. Comenius was concerned himself with global improvement. Why? It conceivably concerned all people and the whole stage of the entire world. The improvement task having been prepared, it was time to set about its completion. The plea for improvement was addressed to everybody - Comenius went beyond the extent of national and European limits and entered 'the stage of the whole world' as a political philosopher, anchored in the Protestant life philosophy and ethics, which is based on the love of freedom for all who take part in it, because love of freedom is innate in human mind.

\section{Conclusion}

At some stages of our historical development Comenius was not only slighted, but his ideas used to be negated. Still, there is one historical fact that proves that whenever the ideas of freedom, humanism and democracy were commended in this country, it was Comenius who stood at the nascent pivotal points in Czech history. When T. G. Masaryk formulated the fundamental document inaugurating the origin of the common state of Czechs and Slovaks - the Declaration of Independence of the Czechoslovak Nation

14 M. Ransdorf, Muž velké touhy (Komenský proti proudu dějin), Praha 1995, p. 78. 
(referred to as the Washington Declaration of 18th October, 1918) - he mentioned Comenius as a great thinker of our nations.

We, the nation of Comenius, cannot but accept these principles expressed in the American Declaration of Independence, the principles of Lincoln, and of the Declaration of the Rights of Man and of the Citizen. For these principles our nation shed its blood in the memorable Hussite Wars five hundred years ago, for these same principles, beside her allies in Russia, Italy, and France, our nation is shedding its blood today 15 .

Comenius' political philosophy represented political conservatism deeply rooted in Protestant philosophy and ethics, whose mainstay was freedom, balanced with responsibilty, self-discipline, self-controle and respect for natural authority. The aim of this paper is to enhance Comenius' portrayal by his achievement in the cultural history of mankind, by the description of a political thinker whose image was obscured by a biased accentuation of his indisputable importance for pedagogy. The multitude of his activities, however, can hardly be separated, just the opposite, for they have become part of monumental pansophical project.

\section{BIBLIOGRAPHY}

Comenius. Erkennen - Glauben - Handeln. Internationales Comenius-Colloquium Herborn 1984. Hrsg. von K. Schaller, Sankt Augustin 1985.

Červenka J., Problematika Komenského metafyziky, Studia Comeniana et historica, 1973, 6.

Gronský J., Hřebejk J., Dokumenty k ústavnímu vývoji Československa I. (1918-1945), Univerzita Karlova, Praha 2004.

Komenský J.A., Obecná porada o nápravě věcí lidských, Vol. III, Svoboda, Praha 1992.

Kumpera J., Jan Amos Komenský, Svoboda, Ostrava 1992.

Pánek J., Politické labyrinty Jana Amose Komenského, Filosofický časopis, 1992, 40, 1.

Pešková J., Aktuální aspekty filosofické argumentace v Komenského "Konzultaci", Filosofický časopis, 1992, 40, 1 .

Popelová J., Filozofia Jana Amosa Komenského, Pravda, Bratislava 1985.

Ransdorf M., Muž velké touhy (Komenský proti proudu dějin), Laguna, Praha 1995.

Somr M., Muže naděje a touhy, posel budoucnosti, Pedagogická fakulta, České Budějovice 1999.

15 J. Gronský, J. Hřebejk, Dokumenty k ústavnímu vývoji Československa I. (1918-1945), Praha 2004, p. 19. 